\title{
Drivers of Cooperation Activity in Kosovo's Agriculture
}

\author{
Shyhrete Muriqi ${ }^{1, *(D)}$, Maria Fekete-Farkas ${ }^{2}$ and Zsolt Baranyai ${ }^{3} \mathbb{D}$ \\ 1 Doctoral School of Management and Business Administration, Szent István University, \\ Gödöllő 2100, Hungary \\ 2 Faculty of Economics and Social Sciences, Szent István University, Gödöllő 2100, Hungary; \\ Farkasne.Fekete.Maria@gtk.szie.hu \\ 3 Metropolitan University, Budapest 1148, Hungary; zbaranyai@metropolitan.hu \\ * Correspondence: Muriqi.Shyhrete@phd.uni-szie.hu; Tel.: +36-7031-452-64
}

Received: 20 March 2019; Accepted: 28 April 2019; Published: 2 May 2019

check for updates

\begin{abstract}
This research aims to determine the demographic and economic factors affecting agriculture cooperation activity in Kosovo. Primary data was collected from 249 farmers in Kosovo through structured questionnaires using the random sampling technique. The results show that the level of cooperation among farmers in Kosovo is low due to the lack of trust in the cooperative institutions. The binary logistic regression analysis used in the study shows that location, gender, age, education level, trust, and farm size have significantly influenced the cooperation activity. Findings also highlight that the farmers who live in rural areas, as well as those who are young and have got a higher level of education and trust, show a higher level of activity associated with cooperation, whereas farms managed by (older) men with lower level of education are less likely to cooperate. Estimation indicates that medium sized farms show a high level of cooperation, which can be statistically verified, and only the type of farming has nonsignificant influence in cooperation.
\end{abstract}

Keywords: Kosovo agriculture; willingness to cooperate; trust; cooperatives

\section{Introduction}

The total area of Kosovo is 1.1 million hectares, and 53\% comprises agricultural land, while $41 \%$ is forest. Kosovo has an approximated population of 1.8 million [1]. More than $62 \%$ of Kosovo's population lives in rural areas. Agriculture was the main economic activity in the country for a long period, with an unsuitable structure of crops, primitive equipment, and deficient performance. There were mainly cereals cultivated, dedicated to food for the population and livestock. The livestock was extremely small, and a race of poor quality dominated [2]. Nowadays the agricultural sector plays an essential function in providing employment opportunities and generating income for people living in rural areas. This sector contributes $12 \%$ to the GDP of Kosovo and accounts for over $25 \%$ of total employment [3]. The total number of persons involved in agriculture in Kosovo is 362,700, and the agricultural farmers who are registered in Kosovo are 130,775 [4]. The total farmland in the country is used by 185,765 farms, out of which 185,424 (99\%) are small farms. Despite the employment creation potential and significance of the sector, Kosovo is facing a negative trade balance, suffering from the excessive volume of imported goods and a relatively low volume of exports [5]. The imported agricultural products from other countries are competing with the local agriculture products making the situation worse [6]. The agriculture sector in Kosovo is described by small farms, low productivity, low efficiency, poor infrastructure, improper land use, limited land consolidation, and incomplete social land privatization with unclear property and land use rights [7]. Additionally, Kosovo has unfavorable farm structures, with an average Utilized Agricultural Area (UAA) per holding of 1.5 ha, fragmented into seven plots, and most of the crop farms are not performing efficiently despite the huge potential for technical efficiency improvement [8]. Some of the problems faced by Kosovo's farmers 
are lack of coordination among small farmers, lack of education and training, limited knowledge in the usage of technology, adversary service, lack of experience, limited market access, and the main concern is the lack of cooperation between farmers [3,9].

The international literature highlights several advantages cooperation may bring about. These may be classified under three main categories: most sources underline the economic benefits arising from cooperatives [10-12], while the past decade has seen a rise in the number of studies that shed light on the social [13-16], and environmental advantages [17-19] that result from collaboration. The cooperation of growers in the agriculture economies, with structural and efficiency problems [20] can be especially influential to the achievement of goals of sustainable development. Sustainable and sustainability have appeared as concepts to help address the negative economic, environmental and social impacts in this generation and future one [21,22]. Cooperation is quite a well-known method among producers in developed and developing countries as well. It happens in a variety of circumstances, varying from informal collaboration among siblings and neighbors at periods from large workload (e.g., hay harvesting) to formal production, transportation, marketing and selling cooperatives. Besides collaborating among themselves, farmers also cooperate with consumers, and institutions [23-26]. Collaboration is essential in empowering farmers, and it is the most important in low socio-economic status areas [27] and is seen as required to develop, apply, and establish new innovative ideas and practices. It is also related to the socio-economic and ecological sustainability of the agri-food sector [28]. Informal cooperation is of constant importance, especially for small-scale, family-run farms. It includes farmers sharing machinery and agricultural know-how and helping one another at times of high workload [29]. Sharing can provide other benefits, including improved access to skilled labor, reduced risk and idea sharing among peer groups of like-minded individuals [30]. It also helps to minimize transaction costs, facilitate costs avoidance, develop a shared vision, initiate a learning process, and allows small farmers to increase their impact on the agri-food system [31]. Such cooperation is similar to the mutual aid that often occurs between relatives and neighbors [29].

The so called "modern" agricultural cooperatives present the most prominent example of formal cooperation [32] which is known as a formal way of organizing collective actions by farmers [33]. Cooperatives have obtained prominent attention in recent years as strategic elements to achieve sustainable economic development and greater social cohesion [34]. It is defined as "mutual aid economic organizations joined voluntarily and operated democratically by the farmers and workers of the similar variety of farm outputs, or by the providers or users of assistance as the same kind of agricultural production and operation" [35]. A farmer cooperative is a legal practical entity by which a group of farmers peruse to enhance their economic outcome in a competitive society [36]. The farmer cooperative simply refers to a business organization that plays a significant role by way of different services (e.g., credit, equity, and information), function (e.g., product buying and selling, transportation, storage, and grading) and welfare (e.g., health care, and education) [36,37]. They link farmers to stakeholders, such as governments, extension agencies, research institutions, and retailers to form a more efficient division of labor networks [38].

Based on the beneficial economic effect of the producers' cooperation [39,40], studies have concluded that the cooperation arrangements among agricultural producers may contribute to the reduction of production costs as well as to the rise in profit from production. Thus cooperation improves the bargaining power of smallholders [41] help minimize the market risk that producers face, improve farmers' trust in adopting technology and improve technical efficiency [42]. It also develops the individual performances of cooperating partners [43]. Furthermore, the local production, processing, and distribution infrastructure become more affordable when farmers collaborate amongst themselves and with the consumers and institutions [44]. Besides the direct economic benefits, the cooperatives provide greater possibilities for the intervention of capital and shows excellent externality in product traceability, product quality, food safety, and industrial chain extension [45-49]. The development of cooperatives is based on the notion of agricultural economic transformation, which aims to find new ways of agricultural development based on existing agrarian production [50-52]. Furthermore, there 
are some other factors that influence the level of implementation of certain collaboration initiatives, such as trust and experience in sharing activities [27,53].

Notwithstanding all the benefits, the level of co-operation among farmers (horizontal integration) and between farmers and processors or traders (vertical integration) is still minimal in Kosovo. Collaboration among farmers is not actualized due to the lack of solidarity and poor governance further making the environment difficult to establish efficient farmers' co-operatives in the country [9]. While some cooperatives and associations do exist in cases of various crops and in many areas, only around $9.6 \%$ among them are considered as active which represent only a small percentage of farmers. Curently the capacity of existing cooperatives is weak [54]. Despite having large processing capacity, most of it remains unused. The challenge for processors is to secure both the quantity and quality of local produce. This situation is dominant in transition countries [55]. Most of these countries indeed suffer from a deficit of cooperative entrepreneurship and trust. Nevertheless, this does not mean that there is no preference for cooperation (e.g., informal cooperation; sharing machinery, labor, etc.) in these countries, the preference for cooperation in transition countries is close to that of the other European countries [56]. The creation of a cooperative can be a big challenge, but also a very significant achievement. Cooperatives would help farmers in Kosovo to become more competitive and profitable in the market. However, requires a high degree of trust in the operation of the cooperating model, knowledge, research, planning, patience, and dedication. Co-operative development may not come early, as planned by the founders [57].

Nevertheless, the changing nature of both European and global agricultural markets combined with the fact that sustainability has become a crucial issue, gaining more urgency with climate change and scarcity of natural resources, requires a reflection on the current situation in the creation of sustainable agriculture cooperatives in Kosovo. Therefore, it is essential to create new mechanisms that require dialogue, trust, and cooperation that do not exist at present. Analysis of the factors influencing cooperation activity is of significance importance in this regard. The present study explores the various factors affecting cooperation activity of farmers in agriculture and their willingness to cooperate and is the pioneering research reviewing this issue.

\section{Materials and Methods}

\subsection{Materials Study Area and Sample Selection}

Kosovo is positioned in the central part of Balkan Peninsula, with a surface area of 10,887 $\mathrm{km}^{2}$. In the Southern part, Kosovo shares its border with Macedonia, in South West with Albania, North West with Montenegro and the North Eastern and South Eastern part With Serbia. Kosovo's continental climate is distinguished by temperature between $-20^{\circ} \mathrm{C}$ during the winter and $+35^{\circ} \mathrm{C}$ during summer. The research was carried out between May to October 2018. Farmers engaged in the cultivation of various vegetables, cereals, and fruits, as well as those who owned animal farms were randomly chosen and interviewed for the study.

\subsection{Questionnaire and Data Collection}

To examine the demographic and economic factors that determine the cooperation activity in the agriculture sector in Kosovo, primary data was collected through a structured questionnaire using the random sampling technique. The questionnaires were firstly pre-tested with a sample size of 20 . Due to the absence of knowledge in using the Internet among farmers, the questionnaires were filled out by hand. The questionnaire was distributed to 300 farmers in the country and out of that 249 farmers responded. The response rate is $83 \%$. We consider it as important to note that the sample in the study can be considered statistically representative at the national level because of the data collection methods used. The sample adequacy test showed that the sample chosen for the study is adequate at $95 \%$ confidence level with a margin of error $6.3 \%$. 


\subsection{Data Analysis}

Data was examined with the statistical package for social sciences (SPSS). Descriptive statistics were used to describe the gathered data and variables. Binary logistic regression was used to check significant factors influencing cooperation activity of farmers. Binary logistic regression sometimes it is called the logistic model or logit model, analyzes the association among multiple independent variables and a categorical dependent variable, and estimates the likelihood of occurrence of an event by suitable data to a logistic curve [58]. The binary values [59,60] is the most important data collected for the study. Using this Model, the factors (X-independent variables) affecting agriculture cooperation activity, and the results (Y-dependent variables) could be measured. The formula used for the analysis is as follows:

$$
\begin{gathered}
\mathrm{Y}=\mathrm{B}_{0}+\mathrm{B}_{1} \text { LOCATION }+\mathrm{B}_{2} \text { GENDER }+\mathrm{B}_{3} \text { AGE }+\mathrm{B}_{4} \text { EDUCATION LEVEL }+\mathrm{B}_{5} \text { TRUST } \\
+\mathrm{B}_{6} \text { TYPE OF FARMING SIZE FARM }+\mathrm{B}_{7} \text { SIZE FARM }+\mathrm{ui}
\end{gathered}
$$

Cooperation among producers happens into two broad categories: formal and informal (Formal cooperation primarily includes collaborations regulated by written contract in accordance with existing legal provisions (e.g., cooperatives, machinery rings and other producer organisations, etc.) while informal cooperation is usually based on verbal agreements made by relatives, friends and acquaintances without its content made compliant with relevant pieces of legislation and with operating conditions shaped by the participants (e.g., paid machine services, reciprocal labour practices, lending of machinery and tools, joint input purchase and sales, joint use of services, etc.) [61]). Informal activities, by their very nature, are less likely to be easily documented and they are more difficult to study since in many cases they belong to the zone of the black and grey economy. In contrast, the theoretical and practical advantages of formal collaborations such as cooperatives and producer organizations have been extensively explored through diverse approaches as evidenced by the vast amount of previous research. Cooperation activity was involved as the binary dependent variable (does not cooperate 0 ; cooperates 1 ).

Seven variables were included in the model (Figure 1) using the Enter Method: I. Location in which the farm is located ((1) urban area; (2) rural area); II Gender: the sex of the responsible leader of the farm ((1) male; (2) female); III Age: the age of the main decision maker of the farm ((1) 15-49 year old; (2) 50-80 year old); IV Education: the highest level of completed education of the leader of the farm ((1) university-level BSc, MSc, or PhD degree; (2) primary/high school); V Level of Trust: the responses of farmers given on a 5-point Likert scale to the following statement: "I think most of my fellow farmers are trustworthy" (1-strongly disagree; 5-strongly agree). VI Type of Farm: the type of agricultural activity ((1) cereals; (2) vegetable; and (3) mix farms); VII Size of Farm: based on hectares per farm ((1) 0.01-5 ha; (2) 5.01-10 ha; (3) 10.01-20 ha; and (4) 20.01-70). Out of the seven variables, II, III, and VII were listed as categorical variables with the last category marked as a reference value in each case.

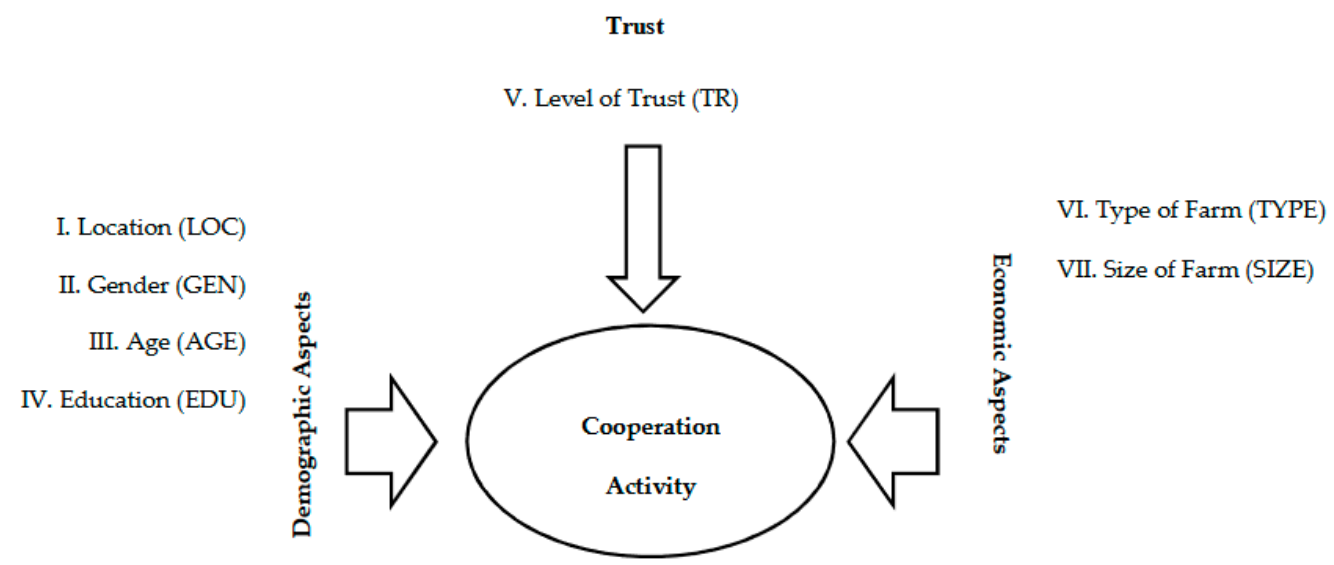

Figure 1. The logical model of the examinations. 


\section{Results}

\subsection{Descriptive Data of Farmers}

Concerning the demographic and economic factors of cooperation activity, the results (Table 1) showed that more than three quarters $(73.3 \%)$ of the farmers in the sample were from the rural area and minor parts and $(27.7 \%)$ was from urban areas. Most of the farms (94.4\%) were managed by males and the rest (5.6\%) by females. The average age of respondents was 46.99 . More than half $(58.6 \%)$ belong to the age of $15-49$, and the rest (41.4\%) were of the age of 50-80. More than three-quarters of farmers had finished primary/higher school (79.5\%), and the rest had finished university (20.5\%). Furthermore, results in the sample showed that most of the farms $(48.2 \%)$ were part of mixed farms (which include, animal farm and fruits) and others were vegetable (37.3\%) and cereals (14.5\%). While the average size of farms was 6.81 ha, most farmers (85.6\%) belonged to the long scale farms 0.01 to $10.00 \mathrm{ha}$, and a minority (14\%) pertains to the scale 10.01 to 70.00 ha. According to the level of trust, most of the respondents (65.5\%) trust on cooperation between farmers, a minor part (19.2\%) does not, and the rest $(15.3 \%)$ does neither agree nor disagree.

Table 1. Farmers' basic characteristics.

\begin{tabular}{ccccc}
\hline Factor & Sort & Frecuency & Perc. $\%$ & Mean \& S.D. ${ }^{*}$ \\
\hline \multirow{2}{*}{ I. Location } & Urban & 69 & $27.70 \%$ & $0.09 \pm 0.284$ \\
& Rural & 180 & $73.30 \%$ & $0.22 \pm 0.413$ \\
II. Gender & Male & 235 & $94.40 \%$ & $0.17 \pm 0.337$ \\
III. Age & Female & 14 & $5.60 \%$ & $0.36 \pm 0.497$ \\
& $14-49$ & 146 & $58.60 \%$ & $0.27 \pm 0.444$ \\
IV. Education Level & 50-80 & 103 & $41.40 \%$ & $0.06 \pm 0.235$ \\
& University & 51 & $20.50 \%$ & $0.31 \pm 0.469$ \\
V. Type of Farming & Primary/higher school & 198 & $79.50 \%$ & $0.15 \pm 0.354$ \\
& Cereals & 36 & $14.50 \%$ & $0.11 \pm 0.319$ \\
& Vegetable & 93 & $37.30 \%$ & $0.19 \pm 0.397$ \\
VI. Size Farm & Mix farms & 120 & $48.20 \%$ & $0.19 \pm 0.395$ \\
& 0.01-5 & 162 & $65.10 \%$ & $0.07 \pm 0.252$ \\
& 5.01-10 & 51 & $20.50 \%$ & $0.57 \pm 0.500$ \\
& 10.01-20 & 24 & $9.60 \%$ & $0.17 \pm 0.381$ \\
& 20.01-70 & 12 & $4.80 \%$ & $0.08 \pm 0.289$ \\
& Likert scale (1-5) & & & \\
& 1. I don't agree at all & 24 & $9.60 \%$ & $0.04 \pm 0.204$ \\
VII. Trust & 2. I don't agree & 24 & $9.60 \%$ & $0.08 \pm 0.282$ \\
& 3. I don't agree or disagree & 38 & $15.30 \%$ & $0.08 \pm 0.273$ \\
& 4. I agree & 117 & $47.00 \%$ & $0.08 \pm 0.293$ \\
& 5. I agree at all & 46 & $18.50 \%$ & $0.61 \pm 0.493$ \\
\hline
\end{tabular}

*Standard Deviation.

Regardless of the high level of trust among farmers, only a small percentage (18.1\%) of farmers in the sample belong to cooperating farmers, and the majority of the farmers $(81.9 \%)$ do not cooperate at all (Figure 2).

Some of the main causes proposed to know the reason why farmers were not a part of any cooperation involve; they do not believe that cooperative can help them (46.3\%) ("I do not believe that the cooperative institution could help me"). They do not agree with the cooperative work ( $31.1 \%)$ ("I do not agree with the way the organizations are running"), and they want to be independent $(11.3 \%)$ ("I want to make up my own decisions and not to depend on others") (Table 2). However, according to survey findings, more than the half $(65.7 \%)$ of farmers are willing to join or participate in any cooperation between each other, as a result of high trust (65.5\%) among farmers (Figure 2). 


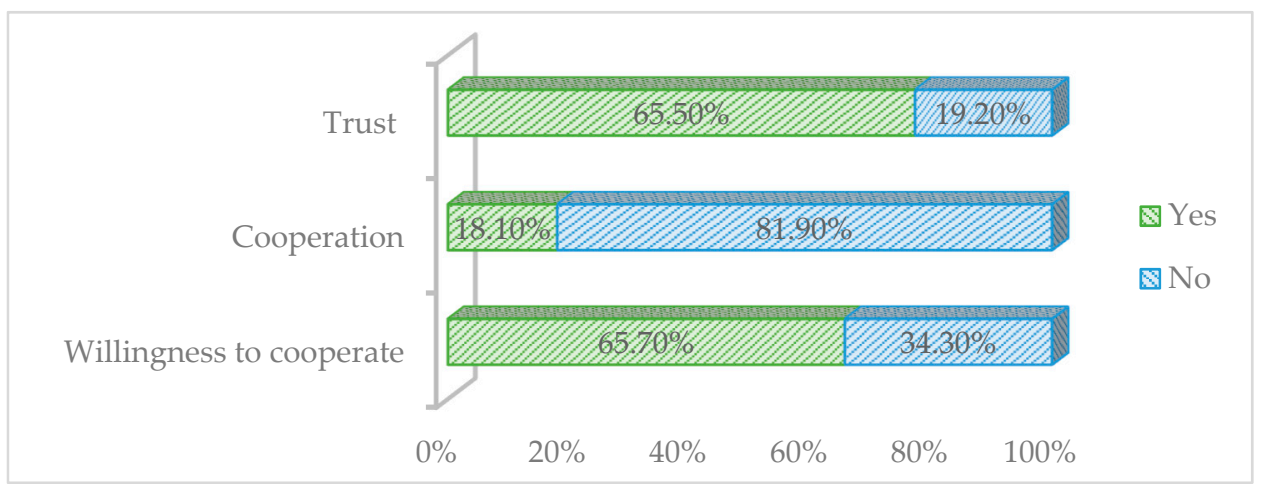

Figure 2. Agriculture cooperation, willingness to cooperate and trust.

Table 2. Reasons for not participating in the agricultural cooperative.

\begin{tabular}{cc}
\hline Reasons & Percentage \\
\hline I sell my products to the same trader/company for many years, and I am satisfied. & $3.9 \%$ \\
I buy my supplies (fertilizers, pesticides) from a particular supplier who also advises me. & $5.8 \%$ \\
I do not believe that a cooperative institution could help me. & $46.3 \%$ \\
I do not agree with the way the cooperatives are running. & $31.1 \%$ \\
I want to make up my own decisions and not to depend on others. & $11.3 \%$ \\
I do not trust others to decide for me. & $6.2 \%$ \\
I have personal differences/disagreements with some other members of the cooperative. & $0.8 \%$ \\
I have personal differences/conflicts with the administrative board of the cooperative. & - \\
The cooperative cannot provide useful services to me. & $1.6 \%$ \\
The cooperatives cannot solve producers' problems (only the state can). & $3.5 \%$ \\
Other reasons & $5.1 \%$ \\
\hline
\end{tabular}

\subsection{Binary Logistic Regression}

The logistic regression model gave a statistically significant result of $\chi^{2}(9)=104.60, p<0.001$. This model explained between (Cox \& Snell R Square) $34 \%$ and (Nagelkerke $\mathrm{R}^{2}$ ) $56 \%$ of the variance in cooperation activity and correctly classified $91.2 \%$ of the cases. Additionally, we received an insignificant values for Goodness-of-fit test (Hosmer and Lemeshow) $\chi^{2}(8)=8.487, p>0.387$. Below Table 3 presents the logistic regression output of the factors determining cooperation activity of farmers in Kosovo.

The result showed that Predicted logit of $($ COOPERATION $)=-7.570+(1.333) *$ LOCATION + $(-1.504) *$ *GENDER + (1.400) *AGE + (-1.307) *EDUCATION LEVEL + (1.210) *TRUST + $(0.185) *$ TYPE OF FARMING + (0.036) *SIZE OF FARM(1) + (2.805) *SIZE OF FARM(2) + (0.484) *SIZE OF FARM(3).

Binary logistic regression (Table 3 ) showed that location, gender, age, education level, trust and size of the farm were significant predictors in cooperation activity. Type of farming was marginally non-significant $(p=0.580)$.

(I) Moreover, the location has a positive significant $(p<0.05)$ relationship in cooperation activity. Furthermore, in the farms which were in urban areas, cooperation was less common in comparison to those in rural areas and also showed a positive tendency to cooperate rather than the urban farmers. As a result, increases of farms located in the rural areas; the odds ratio of cooperation activity increases $3.793(=\beta 1.333)$ times greater as compared to the urban areas. The contrasts between urban and rural areas are depicted by average (Table 1 ) of farmers cooperating in rural area, which is higher $(0.22 \pm 0.413)$ than that of urban area $(0.09 \pm 0.284)$.

(II) The next demographic factor considered in the study is gender which has an important role but negative significance $(p<0.05)$ in the cooperation activity. The farms managed by males corresponded with lower odds of cooperation activity, whereas the farms managed by females are $4.504(1 / 0.222)$ $(=\beta-1.504)$ times more likely to cooperate. The variation between gender shows that the average farms led by females have a higher probability to cooperate $(0.36 \pm 0.497)$, compared to males $(0.17 \pm 0.337)$. 
(III) The other predictor that has positive significance in cooperation activity is the age of farmers $(p<0.05)$. Farmers who are younger, (group 1) 15-49 years old are more likely to cooperate 4.054 $(=\beta 1.400)$ times greater than the older farmers (group 2$) 50-80$ years age group. Increasing number of young farmers is associated with increased cooperation between each other. The average of farmers who cooperate among the younger generation (group 1$)$ is higher $(0.27 \pm 0.444)$, that of the older age (group 2) $(0.06 \pm 0.235)$.

(IV) Education level has a significant negative relationship $(p<0.05)$ in cooperation activity. Higher number of farmers with a low level of education would correspond with lower odds of cooperation, whereas farmers who have a high level of education are $3.690(1 / 0.271)(=\beta-1.307)$ times more likely to cooperate. Moreover, it can be seen in the difference in mean among groups; 1 (university) which cooperate is greater $(0.31 \pm 0.469)$, compared group 2 (primary/higher school) $(0.15 \pm 0.354)$.

(V) It was also noticed that there was a positive significance $(p<0.01)$ between the level of trust and cooperation activity.

(VI) According to the results of economic factors, type of farming does not have a significance $(p>0.05)$ in cooperation activity.

(VII) The last element was the size of farms which has positive significance $(p<0.01)$ in cooperation activity, medium-sized farms $5.01-10.00$ ha (group 2$)$ are more likely to cooperate $16.522(=\beta 2.805)$ times greater, compared to small-sized farms; $0.01-5.00$ ha (group 1 ) and larger-sized farms 10.01-20.00 and 20.01-70 ha (group 3 and 4). This difference is also stressed by means of size farm group (1) $(0.07 \pm 0.252)$, group (2) $(0.57 \pm 0.500)$, group (3) $(0.17 \pm 0.381)$, and group (4) $(0.08 \pm 0.289)$.

As it is showed in Table 3 except the type of farming $(p>0.05)$, all other variables have an impact on cooperation activity. It can be statistically justified $(p<0.05)$ that all the six variables included in the model have an impact on cooperation activity.

Based on the value of $R$ (Papers on methodology recommend the use of the so-called $R$ value to express the role and power of specific independent variables in a model. The size of the value denotes the order of "importance" of independent variables. This index is not a part of the output of the model, it needs to be calculated using the following equation: $R=\sqrt{\frac{\text { Wald-2df }}{D_{0}}}$ ), it can be stated that cooperation activity is mostly (0.316) shaped by the size of the farm (SIZE) followed by the level of trust (TR; 0.250) and the partial impact (0.125) of education level (EDU) and of age (0.124)(AGE).

Table 3. Binary logistic regression; Factors affecting cooperation activity.

\begin{tabular}{cccccccc}
\hline FACTORS & B & S.E. & Wald & Df & Sig. & Exp(B) & R \\
\hline I. LOC & 1.333 & 0.589 & 5.118 & 1 & 0.024 & 3.793 & 0.113 \\
II. GEN & -1.504 & 0.744 & 4.091 & 1 & 0.043 & 0.222 & 0.093 \\
III. AGE & 1.400 & 0.584 & 5.741 & 1 & 0.017 & 4.054 & 0.124 \\
IV. EDU & -1.307 & 0.545 & 5.754 & 1 & 0.016 & 0.271 & 0.125 \\
V. TR & 1.210 & 0.293 & 17.045 & 1 & 0.000 & 3.353 & 0.250 \\
VI. TYPE & 0.185 & 0.334 & 0.306 & 1 & 0.580 & 1.203 & - \\
VII. SIZE & & & 30.103 & 3 & 0.000 & 0 & 0.316 \\
-SIZE HA (1) & 0.036 & 1.230 & 0.001 & 1 & 0.977 & 1.036 & - \\
-SIZE HA (2) & 2.805 & 1.226 & 5.232 & 1 & 0.022 & 16.522 & 0.116 \\
-SIZE HA (3) & 0.484 & 1.306 & 0.138 & 1 & 0.711 & 1.623 & - \\
Constant & -7.570 & 2.379 & 10.127 & 1 & 0.001 & 0.001 & \\
\hline
\end{tabular}

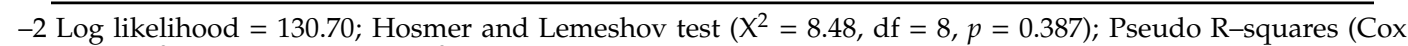
and Snell $R^{2}=34 \%$; Nagelkerke $R^{2}=56 \%$ ); Overall percentage of correctly predicted = $91.2 \%$; B: unstandardized regression weight; S.E.: standard error; Sig.: significance; $\operatorname{Exp}(\mathrm{B})$ : exponentiation of the B coefficient; Wald.: Wald chi-square value; Df.: the degrees of freedom. ("-" Factors that were not shaped in cooperation activity; Farm size "(1)" 0.01-5 ha "(2)" 5.01-10 ha "(3)" 10.01-20 and 20.01-70 ha). 


\section{Discussion}

Research on cooperation activity in agriculture is relatively limited in the literature. Therefore, the findings of this study are of significant importance for better understanding the demographic and economic drivers of cooperation between farmers. Most of the farmers (81.9\%) in Kosovo belong to those who do not cooperate at all. According to our study, cooperation seems to be of a low $(18.1 \%)$ level in Kosovo which is in line with the results of a previous research conducted in 2013 [8], showing little or no progress in the situation over the past five years. It was a surprise to find almost similar results in the case of Hungarian farmers as well [62]. Some of the main reasons identified by this study on the reluctance among farmers in Kosovo to cooperate are that; they do not believe that cooperative institutions can help them (46.3\%), they do not agree with the cooperatives work $(31.1 \%)$ and they want to be independent (11.3\%). Despite this, the level of trust is slightly higher $(65.5 \%)$ and the willingness of the farmers in Kosovo to cooperate (especially buying/sharing agriculture machinery) with other farmers (with their relatives, friends, neighbors) is also higher (65.6\%). From the Figure 2, it is apparent that farmers in Kosovo have a higher level of trust and willingness to cooperate, although the cooperation is very low, taking into consideration that the farmers have not shown willingness to cooperate in a higher level as with the cooperative institution but only in informal cooperation. According to explored factors influencing cooperation activity in the agriculture sector. Binary logistic regression analysis showed that location, gender, age, education level, trust and size of farms were on identified as significant predictors of cooperation and the only factor, type of farming was not a significant predictor of the cooperation activity. Farmers who live in the rural area have a higher probability of 3.79 times greater to join cooperation compared to farmers who live in urban areas; the reason might be that farmers in rural areas are actively engaged in farming practices and there are very few opportunities other than farming available to them. Farms that are managed by males have a lower probability to cooperate with other farmers compared to the farms that are led by females which have a higher chance of 4.50 times more likely to participate. Different results can be found in the study of Baranyai et al. [63]. The reasons for this could be attributed to the fact that women are under represented in political and economic decision-making processes; who also do not have the possibilities for decent, fair-wage, safe employment, and are more likely to work as informal and unpaid laborers [64]. The women's participation in cooperatives has increased over the past 20 years. In consumer cooperatives, most members are women [65] showing a strong female presence in worker cooperatives. Of the new generation, farmers who are younger ( $14-49$ years old) have a probability of 4.05 times greater to cooperate, compared to farmers that are older (50-80 years old). The same results can be found in the study of Baranyai et al. [63]. This can be because of the fact that older farmers always prefer to work with their family members, not with others and they have got great experience in various farming practices. Farmers who have finished the primary/high school have a lower probability to cooperate compared to those who have completed university (BSc, MSc or Ph.D.). The latter have a higher chance of 3.69 times greater to join a cooperation. The same results can be found in the study of Kőszegi [66], Karli et al. [67], and Baranyai et al. [63]. Another predictor that has greater significance in cooperation activity is trust. An increase in the level of trust correspond with a stronger likelihood of cooperation. With regard to the size of farms, medium-sized farms i.e. 5.01 to 10.00 ha are more likely to cooperate about 16.52 times greater, compared to small and larger-sized farms. The same results can be found in the study of Karli et al. [67].

\section{Conclusions}

This study provides relevant new results to identify various factors that influence cooperation activity in agriculture in Kosovo. Results highlight the significant role that demographics and economic factors likewise the level of trust play in the formation of cooperation activity. The descriptive analysis on the demographic indicators portray that farmers who live in rural areas, as well as those who are younger and have got a high level of education show a higher level of cooperation activity that can be statistically verified, whereas farmers who have a low level of education and managed by males are 
less disposed to cooperation.The economic factors emphasize that medium sized farms show a high level of cooperation which can be statistically verified whereas small and large sized farms are less apt to cooperate. In the developing countries such as Kosovo, which has considerable fragmented farm size, cooperation especially of horizontal integration type will play a very important role in increasing the production, negotiating power, returns to scale, and decreases the cost production.

\section{Limitations}

It is important to note that this is a correlative study and has some limitations, which partly belong to the situation in Kosovo where accessibility to internet and knowledge of using the same is very low. The sample size is small because the interviews were conducted individually with each farmer, but it also had the advantage of increasing the willingness to answer and the authenticity of answers. It should also be mentioned that, besides the growing interest of decision makers and researchers, the literature and statistical data on cooperation activity in agriculture in Kosovo are limited.

Author Contributions: Conceptualization, S.M. and Z.B.; methodology, S.M.; software, S.M.; validation, S.M., Z.B. and M.F.-F.; formal analysis, S.M.; investigation, M.F.-F.; resources, S.M.; data curation, S.M.; writing-original draft preparation, S.M.; writing—review and editing S.M., M.F.-F. and Z.B.; visualization, S.M.; supervision, M.F.-F. and Z.B.

Funding: This research received no external funding.

Conflicts of Interest: The authors declare no conflict of interest.

\section{References}

1. Ministry of Environment and Spatial Planning. Kosovo Environmental Protection Agency State of Environment in Kosovo 2015. Available online: http://ammk-rks.net/repository/docs/Anglisht-final.pdf (accessed on 1 January 2019).

2. Reçica, F. Structural characteristics of Kosova's economy. AAB Coll. 2009, 25-50.

3. Gjokaj, E.; Halimi, K.; Gjonbalaj, M.; Leeds, S. Agricultural Finance in Kosovo. Econ. Altern. 2017, 79-88.

4. Agriculture Registration in the Republic of Kosovo; Kosovo Agency of Statistics: Pristina, Kosovo, 2014; pp. 1-258.

5. Jusufi, G.; Mahmutaj, L.R.; Jusufi, G.; Jusufi, N. Kosovo's International Trade: Balance of Trade. Eur. J. Econ. Bus. Stud. 2015, 3, 58-69. [CrossRef]

6. Sallahu, S.; Gjokaj, E. The Potential of Agriculture in Developing Kosovo's Economy. In Presented at the Proceedings of the International Conference of the DAAD Biodiversity Network Project 'Agriculture and biodiversity on the Balkan Peninsula', Prishtina, Kosovo, October 2016; 2016; pp. 1-10.

7. GREEN REPORT KOSOVO; Ministry of Agriculture, Forestry and Rural Development: Lisbon, Portugal, 2013; pp. 1-146.

8. Miftari, I.; Gjokaj, E.; Zvyagintsev, D. Efficiency Measurement of Kosovo Crop Farms Data Envelopment Analysis. In Proceedings of the XV EAAE Congress-Towards Sustainable Sustainable Agri-Food Systems: Balancing between Markets and Society, Parma, Italy, 28 August-1 September 2017; p. 1.

9. European Fund for Southeast Europe AGRICULTURAL FINANCE IN KOSOVO. Available online: http://www.efse.lu/uploads/tx_news/Agricultural_Finance_in_Kosovo.pdf (accessed on 1 December 2018).

10. Franks, J.; Mc Gloin, A. Environmental Co-operatives as Instruments for Delivering Across-Farm Environmental and Rural Policy Objectives: Lessons for the UK. J. Rural Stud. 2007, 23, 472-489. [CrossRef]

11. Valentinov, V. Why are cooperatives important in agriculture? An organizational economics perspective. J. Institutional Econ. 2007, 3, 55-69. [CrossRef]

12. Falco, S.D.; Smale, M.; Perrings, C. The role of agricultural cooperatives in sustaining the wheat diversity and productivity: The case of southern Italy. Environ. Resour. Econ. 2008, 39, 161-174. [CrossRef]

13. Wynne-Jones, S. Understanding farmer co-operation: Exploring practices of social relatedness and emergent affects. J. Rural Stud. 2017, 53, 259-268. [CrossRef]

14. Ajates Gonzalez, R. Going back to go forwards? From multi-stakeholder cooperatives to Open Cooperatives in food and farming. J. Rural Stud. 2017, 53, 278-290. [CrossRef]

15. Forney, J.; Häberli, I. Co-operative values beyond hybridity: The case of farmers' organisations in the Swiss dairy sector. J. Rural Stud. 2017, 53, 236-246. [CrossRef] 
16. Vladimirova, V. Producers' cooperation within or against cooperative agricultural institutions?: The case of reindeer husbandry in Post-Soviet Russia. J. Rural Stud. 2017, 53, 247-258. [CrossRef]

17. Emery, S.B.; Franks, J.R. The potential for collaborative agri-environment schemes in England: Can a well-designed collaborative approach address farmers' concerns with current schemes? J. Rural Stud. 2012, 28, 218-231. [CrossRef]

18. Asai, M.; Langer, V. Collaborative partnerships between organic farmers in livestock-intensive areas of Denmark. Org. Agric. 2014, 4, 63-77. [CrossRef]

19. Martin, G.; Moraine, M.; Ryschawy, J.; Magne, M.-A.; Asai, M.; Sarthou, J.-P.; Duru, M.; Therond, O. Crop-livestock integration beyond the farm level: A review. Agron. Sustain. Dev. 2016, 36, 53. [CrossRef]

20. Pavillard, N. Innovative Bewirtschaftungsformen und Strukturanpassungen in der Schweizer Landwirtschaft. Innovative management forms and structural adjustments in Swiss agriculture. Ph.D. Thesis, Swiss Federal Institute of Technology Zurich Institute of Agricultural Economics, Zürich, Switzerland, September 2005.

21. da Silva Batista, A.A.; de Francisco, A.C. Organizational Sustainability Practices: A Study of the Firms Listed by the Corporate Sustainability Index. Sustainability 2018, 10, 226. [CrossRef]

22. Lozano, R. Envisioning sustainability three-dimensionally. J. Clean. Prod. 2008, 16, 1838-1846. [CrossRef]

23. Anderson, C.; Brushett, L.; Gray, T.; Renting, H. Working Together to Build Cooperative Food Systems. J. Agric. Food Syst. Community Dev. 2014, 3-9. [CrossRef]

24. Schermer, M. From "Food from Nowhere" to "Food from Here:" changing producer-consumer relations in Austria. Agric. Hum. Values 2015, 32, 121-132. [CrossRef]

25. Renting, H.; Schermer, M.; Rossi, A. Building Food Democracy: Exploring Civic Food Networks and Newly Emerging Forms of Food Citizenship. Int. J. Soc. Agr. Food, 2012; 19, $289-307$.

26. Brunori, G.; Rossi, A. Co-producing Transition: Innovation Processes in Farms Adhering to Solidarity-based Purchase Groups (GAS) in Tuscany, Italy. Int. Jrnl. Soc. Agr. Food 2010, 18, 28-53.

27. Dania, W.A.P.; Xing, K.; Amer, Y. Collaboration behavioural factors for sustainable agri-food supply chains: A systematic review. J. Clean. Prod. 2018, 186, 851-864. [CrossRef]

28. Sutherland, L.-A.; Darnhofer, I.; Wilson, G.; Zagata, L. Transition Pathways towards Sustainability in Agriculture: Case Studies from Europe; CABI: Wallingford, UK, 2014; ISBN 978-1-78064-219-2.

29. Cialdella, N.; Dobremez, L.; Madelrieux, S. Livestock Farming Systems in Urban Mountain Regions: Differentiated Paths to Remain in Time. Outlook Agric. 2009, 38, 127-135. [CrossRef]

30. Artz, G.; Naeve, L. The Benefits and Challenges of Machinery Sharing Among Small-scale Fruit and Vegetable Growers. J. Agric. Food Syst. Community Dev. 2016, 1-17. [CrossRef]

31. Erkuş-Öztürk, H.; Eraydın, A. Environmental governance for sustainable tourism development: Collaborative networks and organisation building in the Antalya tourism region. Tour. Manag. 2010, 31, 113-124. [CrossRef]

32. Cobia, D.W. Cooperatives in Agriculture; Prentice-Hall: Englewood Cliffs, NJ, USA, 1989; ISBN 978-0-13-172461-7.

33. Madelon Meijer, J.H. Mark Lundy Farmer Organization, Collective Action and Market Access in Meso-America. CAPRI Work. Pap. 2007, 1-37.

34. Bretos, I.; Marcuello, C. Revisiting globalization challenges and opportunities in the development of cooperatives: Revisiting globalization challenges and opportunities for cooperatives. Ann. Public Coop. Econ. 2017, 88, 47-73. [CrossRef]

35. Wu, X.; Ding, Y. The Service Supply Effect of Cooperatives under Economic Transformation: A DemandSupply Perspective. Sustainability 2018, 10, 3075. [CrossRef]

36. Kohls, R.L.; Uhl, J.N. Marketing of agricultural products. Macmillan Publ. Co. 1990, 545. [CrossRef]

37. Prakash, D. Development of agricultural cooperatives-Relevance of Japanese experiences to developing countries. Presented at the 14th ICA-Japan International Training Course on "Strengthening Management of Agricultural Cooperatives in Asia", Tokyo, Japan, 18 April 2000.

38. Yang, H.; Klerkx, L.; Leeuwis, C. Functions and limitations of farmer cooperatives as innovation intermediaries: Findings from China. Agric. Syst. 2014, 127, 115-125. [CrossRef]

39. Istvan, N.; Istvan, T. Importance of saving machinery using - and farmers helping cooperations in the agriculture - Easter-European countries. Rocz. Nauk. Stowarzyszenia Ekon. Rol. Agrobiznesu 2001, 5, 128-130.

40. Larsén, K. Economic Consequences of Collaborative Arrangements in the Agricultural Firm; Swedish University of Agricultural Sciences: Uppsala, Sweden, 2008.

41. Bijman, J.; Hu, D. The Rise of New Farmer Cooperatives in China: Evidence from Hubei Province. J. Rural Coop. 2011, 99-113. 
42. Abebaw, D.; Haile, M.G. The impact of cooperatives on agricultural technology adoption: Empirical evidence from Ethiopia. Food Policy 2013, 38, 82-91. [CrossRef]

43. Smith, K.G.; Carroll, S.J.; Ashford, S.J. Intra- and Interorganizational Cooperation: Toward a Research Agenda. Acad. Manage. J. 1995, 38, 7-23. [CrossRef]

44. Lutz, J.; Smetschka, B.; Grima, N. Farmer Cooperation as a Means for Creating Local Food Systems-Potentials and Challenges. Sustainability 2017, 9, 925. [CrossRef]

45. Jia, X.; Huang, J.; Xu, Z. Marketing of farmer professional cooperatives in the wave of transformed agrofood market in China. China Econ. Rev. 2012, 23, 665-674. [CrossRef]

46. Liang, Q.; Huang, Z.; Lu, H.; Wang, X. Social Capital, Member Participation, and Cooperative Performance: Evidence from China's Zhejiang. Int. Food Agribus. Manag. Rev. 2015, 18, 30.

47. Giagnocavo, C.; Bienvenido, F.; Ming, L.; Yurong, Z.; Antonio Sanchez-Molina, J.; Xinting, Y. Agricultural cooperatives and the role of organisational models in new intelligent traceability systems and big data analysis. Int. J. Agric. Biol. Eng. 2017, 10, 115-125. [CrossRef]

48. Zhang, M.; Jin, Y.; Qiao, H.; Zheng, F. Product quality asymmetry and food safety: Investigating the "one farm household, two production systems" of fruit and vegetable farmers in China. China Econ. Rev. 2017, 45, 232-243. [CrossRef]

49. Ji, C.; Jia, F.; Trienekens, J. Managing the pork supply chain through a cooperative: The case of Jinzhong Food Co. Ltd. Int. Food Agribus. Manag. Rev. 2017, 20, 415-426. [CrossRef]

50. Yu, B.; Liu, F.; You, L. Dynamic Agricultural Supply Response Under Economic Transformation: A Case Study of Henan, China. Am. J. Agric. Econ. 2012, 94, 370-376. [CrossRef]

51. Long, H.; Zou, J.; Pykett, J.; Li, Y. Analysis of rural transformation development in China since the turn of the new millennium. Appl. Geogr. 2011, 31, 1094-1105. [CrossRef]

52. Qin, Y.; Zhang, X. The Road to Specialization in Agricultural Production: Evidence from Rural China. World Dev. 2016, 77, 1-16. [CrossRef]

53. Panahifar, F.; Byrne, P.J.; Salam, M.A.; Heavey, C. Supply chain collaboration and firm's performance: The critical role of information sharing and trust. J. Enterp. Inf. Manag. 2018, 31, 358-379. [CrossRef]

54. Allen Hamilton, B. Kosovo Agricultural Opportunities Strategy. Available online: http://www.agrowebcee.net/ fileadmin/content/awkosovo/files/kosovo_ag_strategy_report_full_20deliverable_final_February_10_09_june_ 10_1_.pdf (accessed on 18 October 2018).

55. Borzaga, C.; Spear, R. Trends and Challenges for Co-operatives and Social Enterprises in Developed and Transition Countries; Fondazione Cariplo: Trento, Italy, 2004; ISBN 978-88-88224-19-0.

56. Lissowska, M. The deficit of cooperative attitudes and trust in post-transition economies. Pap. Evol. Polit. Econ. 2013, 1-37.

57. Pllashniku, M. The Role of Development of Farmers' Cooperatives. Eur. J. Soc. Sci. Educ. Res. 2015, 4, 87. [CrossRef]

58. Park, H.-A. An Introduction to Logistic Regression: From Basic Concepts to Interpretation with Particular Attention to Nursing Domain. J. Korean Acad. Nurs. 2013, 43, 154. [CrossRef] [PubMed]

59. Field, A. Discovering Statistics Using SPSS, 3rd ed.; SAGE Publications Ltd: Los Angeles, CA, USA, 2009; ISBN 978-1-84787-907-3.

60. Gujarati, D. Essentials of Econometrics, 3rd ed.; The McGraw-Hill Companies: New York, NY, USA, 2006; ISBN 978-0-07-297092-0.

61. Bende-Szabó, G.; Baranyai, Z. Economic and Social Barriers to Cooperative Cooperation, Macro and Microeconomic Conditions, and Development Opportunities in the Hungarian Food Industry; Agroinform Kiadó: Budapest, Hungary, 2017; ISBN 978-615-5666-16-2.

62. Baranyai, Z.; Béres, D.; Szabó, G.G.; Vásáry, M.; Takács, I. Factors of trust in machinery sharing arrangements. Ann. Pol. Assoc. Agric. Agribus. Econ. 2011, 13, 18-22.

63. Baranyai, Z.; Elam, Á.; Muriqi, S.; Papp-Váry, Á. Drivers of Cooperation Activity in Hungarian Agriculture. Rocz. Nauk. Stowarzyszenia Ekon. Rol. Agrobiznesu 2018, 20, 9-15. [CrossRef]

64. Committee for the Promotion and Advancement of Cooperatives Cooperatives, Women \& Gender Equality. Available online: http://www.copac.coop/wp-content/uploads/2015/07/COPAC_PolicyBrief_ CoopsWomen.pdf (accessed on 15 January 2019).

65. Suzuki, T. A Brief Chronicle of the Modern Japanese Consumer Cooperative Movement. Available online: https://jccu.coop/eng/public/pdf/a_brief_chronicle.pdf (accessed on 9 January 2018). 
66. Kőszegi, I.R. The young farmers' willingness to cooperate and their chances to get a property of land. The case of Homokhátság. Rocz. Nauk. Stowarzyszenia Ekon. Rol. Agrobiznesu 2016, 18, 190-197.

67. Karlı, B.; Bilgic, A.; Ç Elik, Y. Factors Affecting Farmers' Decision to Enter Agricultural Cooperatives Using Random Utility Model in the South Eastern Anatolian Region of Turkey. J. Agric. Rural Dev. Trop. Subtrop. 2006, 107, 115-127. article distributed under the terms and conditions of the Creative Commons Attribution (CC BY) license (http://creativecommons.org/licenses/by/4.0/). 